Meta

Journal des traducteurs

Translators' Journal

\title{
Translation through Visualization
}

\section{Paul Kußsmaul}

Volume 50, numéro 2, avril 2005

Processus et cheminements en traduction et interprétation

Processes and Pathways in Translation and Interpretation

URI : https://id.erudit.org/iderudit/010943ar

DOI : https://doi.org/10.7202/010943ar

Aller au sommaire du numéro

\section{Éditeur(s)}

Les Presses de l'Université de Montréal

\section{ISSN}

0026-0452 (imprimé)

1492-1421 (numérique)

Découvrir la revue

\section{Citer cet article}

Kußmaul, P. (2005). Translation through Visualization. Meta, 50(2), 378-391. https://doi.org/10.7202/010943ar

\section{Résumé de l'article}

Il y a beaucoup d'aspects différents de la traduction professionnelle. La résolution des problèmes est certes un de ces aspects et la visualisation est des fois recommandée dans ce contexte. Dans cet article, les TAPs - protocoles de dialogue - viennent à être analysés dans le but d'observer les moments de visualisation qui mènent à de bonnes traductions. Des notions cognitives viennent à être employées en tant que moyen heuristique (prototypes, scenes and frames ainsi que le focus). En général, il semble que la visualisation de détails d'une scène aide le traducteur à trouver des solutions créatrices. 


\title{
Translation through Visualization
}

\author{
PAUL KUSSMAUL \\ Johannes Gutenberg University, Mainz, Germany \\ pkussmaul@aol.com
}

\begin{abstract}
RÉSUMÉ
Il y a beaucoup d'aspects différents de la traduction professionnelle. La résolution des problèmes est certes un de ces aspects et la visualisation est des fois recommandée dans ce contexte. Dans cet article, les TAPs - protocoles de dialogue - viennent à être analysés dans le but d'observer les moments de visualisation qui mènent à de bonnes traductions. Des notions cognitives viennent à être employées en tant que moyen heuristique (prototypes, scenes and frames ainsi que le focus). En général, il semble que la visualisation de détails d'une scène aide le traducteur à trouver des solutions créatrices.
\end{abstract}

\begin{abstract}
There are many aspect of professional translation. Problem solving is certainly one of them, and visualization has occasionally been recommended in this context. In this article, think aloud protocols (dialogue protocols) are analysed with the aim of observing instances of visualizations that lead to successful translations. As a heuristic means cognitive notions (prototypes, scenes and frames and focus) are used. In general, it seems that visualizing details of a scene helps translators to arrive at creative translations.
\end{abstract}

\section{MOTS CLÉS/KEYWORDS}

problem solving, creativity, visualization, cognitive processes, TAP studies

\section{Preliminaries}

\subsection{Problem solving}

Technological tools hold a strong fascination for many translators. They love to imagine situations where a precise target equivalent, be it a technical term, a string of words or even a number of sentences, could be made to appear on the computer screen with a mere mouse click. Or even more conveniently, just by fixing his gaze on a word a translator would be able to make his computer come up with a translation. Such tools, no doubt, would minimize mental effort and increase speed. They would greatly improve routine processes.

I am not concerned here with routine processes. They are important for speedy translating, and speed is one of the most important factors in the business. (Cf. Wilss 1992; 1996.) But then, as we all know, pace often slows when problems occur. Translators have experienced these situations when the material provided by their online dictionary, translation memory program or terminology data bank is just not good enough. They then have to switch from routine to problem solving. I would argue that for translators, skills in problem solving are just as important as routine and the knowledge of how to use technology. Problem solving may even, when practised frequently, in the end become a routine. This still awaits investigation (Cf. Kussmaul 2000: 202f.). 
Within the scope of process studies, problem solving by professional translators has been a focus of attention for a number of years. It seems that professionals have global strategies for solving individual problems, and these global strategies are sometimes automatized as well (cf. the survey article by Opitz 2004: 668f.). In this paper I shall look at these professional ways of problem solving more closely. There are occasional hints in the studies on professional translation that visual clues are indeed used (Barbosa/Neiva 2003: 150).

In addition to research by individual scholars, there is combined research by groups. Five groups that investigate translation competence focussing on problem solving have come to my attention. There is PACTE (Process in the Acquisition of Translation Competence and Evaluation) in Spain, which pursues longitudinal studies with the aim of finding out about translational competence as a learning process (cf. PACTE group 2003). There is CORPRAT (Corpus on Process for the Analysis of Translation) in Brazil, designed to investigate the acquisition of translation competence, the role of inferential processes, problem solving and decision making (cf. Pagano et al. 2004). At the Federal University of Rio de Janeiro (UFRJ) there is also the PRONIT (Process and Product in Translation Investigation) research group, which aims at finding out about professional behaviour with a view toward devising a framework for formal training (cf. Barbosa/Neiva 2003). In Europe at the Copenhagen Business School there is the TRAP (Translation Process) group, which is investigating professionalism by comparing it with students' behaviour (cf. Hansen ed. 1999). Finally there is EXPERTISE (Expert Probing through Empirical Research on Translation Processes) headed by Antin Fougner Rydning at the University of Oslo, which applies cognitive and psycholinguistic methodologies to translation processes with the aim of researching expertise in translation. I am actually a member of this group (cf. Kußmaul 2003; for further information consult their website $<$ http://www.hf.uio.no/kri/expertise/>). All these groups make use of electronic tools such as Proxy and Translog. Translog, which I have been using myself, is a computer program that records all keyboard activities and saves the subjects' target texts into a log file after they have completed their task. The research groups use these technologies for online data gathering and to replay the translation process in combination with think-aloud or retrospective protocols, a method that has recently been called triangulation (cf. Alves 2003).

I have dealt with research activities at some length because it is within this frame of investigating professionalism that I want to see my observations on visualization. My hypothesis is that when solving problems of meaning in translation, visualization may be helpful. More specifically, visualization during source text comprehension may offer a stimulus for translation. In interpreting visualization was recognized as a method as early as 1968 by Danica Seleskovitch (I am referring to the English translation of her book L'interprète dans les conférences internationales, 1978: 55), and it was explicitly recommended as a teaching method by Seleskovitch and Lederer (1989: 24-26). In this paper I am looking at some empirical material in order to find out how visualization actually works.

There is some affinity between visualization and creativity, a topic I have been interested in for quite some time. Arthur Koestler put forward the hypothesis that creative thought is visual thought (Koestler 1966: 174-182). In creative translation visualizations lead to shifts, transpositions, modulations etc., in other words, the 
translation involves changes when compared with the source text, thereby bringing in something that is novel. The changes, of course, have to be appropriate to the task that was set, i.e. the translation assignment (For a detailed discussion of what is creative in translation cf. Kußmaul 2000: 17-35.).

Visualization in communication is not a new topic. In order to explain the notion before dealing with it in the translation process, I shall pick out two fields where it has been used for quite some time.

\subsection{Visualization in technical writing}

Visualization is a method firmly established in technical writing. When talking about the different parts of a machine, for instance, pictures, schematic drawings or diagrams are often used to complement the written text, thus facilitating comprehension. Pictograms are sometimes used on their own to refer to things, states of affairs, emotions etc. or even for symbolizing speech acts (cf. Göpferich 1998: 41-60).

For instance, the following figure is a conventionalized item for justice and the law.

FIGURE 1

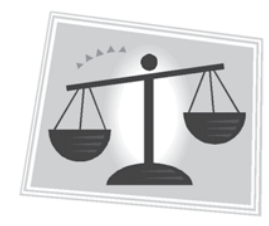

The next figure may by used to symbolize sadness:

FIGURE 2

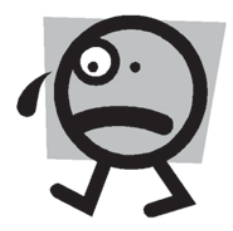

The icons we find in Microsoft Word in the tool bar on the screen symbolize speech acts. For instance, the icon of a printer stands for the directive speech act "Print!." The icon of a diskette stands for "Save!." And binoculars stand for "Look for!."

We can use pictures, pictograms and icons successfully for communication because we rely on the faculty of our mind to think visually. It is not only the things we see, however, such as the different parts of a printer, or actions that we can observe, such as the instructions on how to use your coffee machine, that are communicated in this way. Our mind can also process abstract concepts visually. Thus the figure of a scale (Figure 1), as we saw, does not stand for weighing in a literal sense; it is a conventionalized symbol of justice. And sadness, symbolized by Figure 2, is an emotion, basically invisible and hidden in our soul, although emotions can become observable in facial expressions and in our posture. Figure 2, indeed, shows such visual features of sadness. There is a tear and a curved-down mouth. One might debate whether these features are prototypical. I shall come back to prototypicality later. 


\subsection{Visualizations in dictionaries}

Before turning to translation, I would like to mention another use of visualizations. In some dictionaries, definitions of words are occasionally accompanied by pictures. In the Longman Dictionary of Contemporary English (DCE) we find the following definition for hug:

1 to put your arms around someone and hold them tightly to show love or friendship Synonym embrace: We stood there crying and hugging each other. She went to her daughter and hugged her tightly.

In the electronic version of the DCE there is also a picture:

FIGURE 3

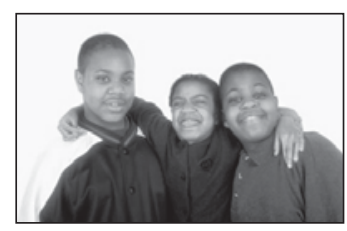

The dictionary makes use of two media, words and pictures, thus making a double imprint, as it were, on our memory. Pictures are used in dictionaries to show the meanings of words to people who do not yet know them or do not know them well enough. We may also turn things round and say that people who know the words form their own mental images of their meaning when hearing or reading them. Thus, when we hear a sentence such as She hugged her two brothers, we might see a picture similar to the one in Figure 3 before our inward eye. We will see a picture that is in accordance with our own experiences, but here again prototypicality will be a feature worth considering (see below). We shall see that it is this process of forming mental images when we hear or read words that helps us find a translation.

\subsection{Empirical observations}

I have often observed this phenomenon in experiments where I asked two subjects to translate a text and talk about it while doing so (cf. Kußmaul 2000). I have also made use of the visualization method in the classroom (cf. Kußmaul 2000: 199-203). I shall report about both kinds of situations and present some new material collected in seminars in the years 2003 and 2004.

When working empirically, i.e. observing material and analysing it, the question arises as to whether the material is representative. This is a problem in studies where, for instance, learners are compared with professionals in order to observe typical, i.e. average, features of behaviour. The sample ought to be chosen carefully, and ideally, it should be randomized. Often the sample is too small to be of statistical relevance.

I am not concerned, however, with average behaviour. My focus is on problem solving. In fact, I am concerned with exceptional, that is, exceptionally successful, behaviour. I am happy to be able to observe just a few cases where problem solving leads to creative translations. My observations can thus be placed within the category of case studies.

A case in my studies, however, does not refer to the behaviour of one specific person all the way through while he or she translates a text but it rather refers to the 
way a specific problem in a text is solved. In other words, even professionals may have dull moments, while producing generally good translations, and students, although not yet professional, may have brilliant ideas, as I shall show in a moment. What I propose to do then is focus on successful processes that bring about good translations, no matter in whom they take place. Moreover, it does not matter if one person or two people are involved, since my focus is not on the persons themselves but on the way the human mind works in specific situations; and as in brainstorming sessions, several minds may work better than one.

As to my hypothesis that for solving problems of meaning in translation visualization may be helpful, my presentation of a few cases is intended to show that there are various kinds of visualizations and that they have a specific effect on the translation process.

For my analysis I shall make use of Fillmore's notions of scene and frame, which is based on prototype semantics (cf. Fillmore 1976 and 1977; Lakoff 1987). I see frames and scenes as metaphors. Scenes are mental images within a frame. The translation process can thus be illustrated with the following figure:

FIGURE 4

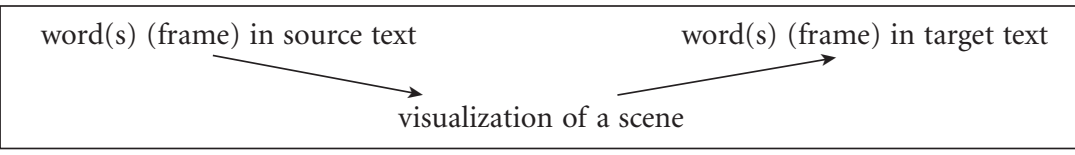

When dealing with problems of meaning, there is no direct path from sourcetext word to target-text word. (As I said above, I am not dealing with unproblematic cases where direct equivalences exist and where routine processes are involved. I am dealing with problems.) What the translator does (or should do) is visualize a scene fitting the word (or frame, in Fillmore's terms). This scene will then (with a bit of luck, that is creativity) stimulate a target frame, that is, a translation. I thus make use of the notion "frame" when interpreting the source text but I also use it when discussing the translation.

I shall also make use of the notion of focus. (Cf. Langacker 1987: 120-127.) We can sometimes observe that the translation, when compared with the source text, focuses on a different aspect of the scene.

\section{Different kinds of stimuli}

\subsection{Looking at real pictures}

The scenes thus visualized are normally mental images but not physically visible pictures. For a start, however, in order to show more clearly what happens, I am using an example where the picture is indeed physically visible. I am reporting on a small experiment carried out by students of mine in a seminar in 2003. They had asked two fellow students to translate a text of the film $O$ Brother, printed on the DVD cover, into German and to talk about what they were doing when translating. When my students presented their paper about their experiment, they also asked the seminar members to translate text. The members (me included) found that the text was hardly comprehensible on its own, although it was probably intended to be understood 
even without the accompanying picture of a scene from the film. The text ran as follows:

Led by smooth talking Everett Mc Gill (George Clooney), three escaped convicts make their break for freedom from a chain-gang in Depression era Mississippi. Mc Gill talks the other two into the daring escape with the lure of a substantial stash of cash, buried after an armoured car heist.

We had a problem with how to understand "chain-gang." As the text says, the convicts had escaped. We were not sure how to understand "freedom from a chain gang" and were wondering if the convicts had to escape twice.

The two subjects who translated the text and talked about it did not seem to have this problem. (The dialogue here and in the following examples was originally in German. I translated it into English.)

A: Three gangsters ... on day release.

B: They aren't on day release, you know ... they are supposed to work outside the prison and are chained to each other to prevent them from running away.

A: Stupid, isn't it?

B: In the film they are chained.

A: Yes.

B.: We can write "schaffen drei aneinander gekettete Gangster den Ausbruch in ... [three convicts chained to each other manage to escape]

A: What the text means isn't merely that they are chained to each other but also that they have to work. It's not that simple.

B: Well ... what do you call this when they work outdoors?

A: I've no idea.

[short pause]

$[\ldots]$

B: While working in field. Looks as if they were running through a field

The final version was:

“...brechen drei aneinander gekettete Gangster bei einem Arbeitseinsatz aus"

(... three chained gangsters make a break for freedom while working)

Although they were on the wrong track briefly with day release the subjects had a pretty clear understanding of the scene. The reason was that they could see the picture on the DVD cover, and this was the picture:

FIGURE 5

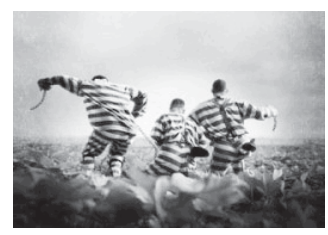

The picture helped the subjects to come up with "Arbeitseinsatz" for their translation.

There is a problem with the picture, however, which was pointed out to me by Don Kiraly (personal communication). Those who have seen the film will remember that the convicts were not working in a field at all. They were working on a road (one of the most common tasks of chain groups). If the subjects had watched just the first five minutes of the film, they would have known that. It is interesting to see that the 
subjects do not have an accurate picture of what is going on in the snapshot. Incorrect inferences are at work here because of a lack of background knowledge. The subjects are missing the "big picture." Still, the subjects make use of visualization, and "Arbeitseinsatz" works fine in the translation, but the translation could have gone wrong.

We may fill in the scene of our example in Figure 4 to illustrate the translation process:

FIGURE 6

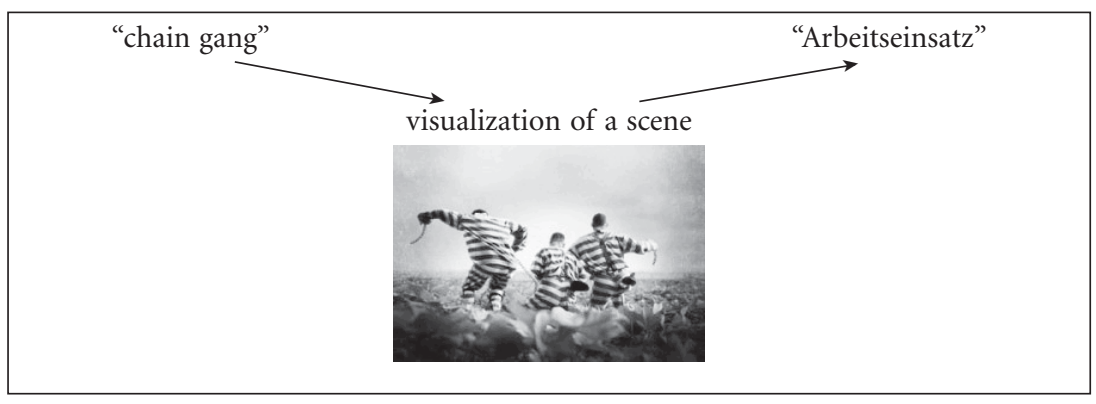

In fact, the translation is much clearer than the original. We may say that the text on its own provides insufficient information and that only with the help of a picture we can really understand what is happening. This is probably a special case, and one might say that optimally the source text should have given more detailed information, for instance that the chained convicts were working on a road and escaped running through a field. Part of this information was here added by means of a picture, and the subjects did not have to imagine the scene on their own, they really saw it, at least some of it, and they were lucky to find a suitable target word.

In cognitive terms, although the scene here was not a mental but a physical picture, the important result is that viewing the scene leads to a creative translation. The source-text frame is replaced with a target-text frame, and the frames are linked by a scene, albeit - with the road work missing - an incomplete one. We can observe a change of focus in the translation. In the source text the focus is on the convicts (three escaped convicts make their break for freedom from a chain-gang), in the target text the focus is on their specific labour situation (Arbeitseinsatz). We may say that it is this change of focus, since it adds something that was not in the source text explicitly, that makes the translation a creative one.

\subsection{Scene suggested by a frame in the source text}

In class we translated a text from Newsweek in which the author looked critically at the medical profession's obsession with technology. There were two instances (underlined words) in the text that caused problems:

Will they [the doctors] be able to guide frightened, vulnerable people through life-anddeath decisions and know when to stop? Or will the machines take on a life of their own, as doctors who have never really learned to listen or to touch become appendages to computers? 
We have gotten to where we simply don't feel cared for unless we are on the frontier of technology. "No MRI scan? What's the matter, aren't I good enough?" "No genetic screen? Don't stint, Doc, I want the best." But technology can come between us and our doctors, who may be afraid to talk to patients and their families? and even more afraid to touch them in today's litigious atmosphere. Doctors are rarely sued for applying high technology, but they are often sued for omitting it.

(Newsweek, July 18, 2001)

The problem was how to translate touch. It was not a question of comprehension. It was clear to us that touch here meant what a doctor does when trying to find out about a patient's pain, but touching a person, especially in countries like the U.S.A. these days, might also be regarded as a kind of sexual intrusion and criminal offence ("litigious atmosphere"). The German equivalent berühren was discarded as it was felt it would only carry the sexual overtones and would not be the word used by a doctor when examining patients.

I then asked the students to imagine a visit at a doctor's surgery. I tried to lead them along by quoting typical phrases a doctor would use, such as "Where do you feel pain?" or "Would you please take off your shirt and lie down." In cognitive terms, I made them remember knowledge stored in their memory? a top-down process. Spontaneously then one of my students came up with "abtasten," which is the very word German doctors use.

As a method in the classroom, it may be added, this ideally presupposes a special way of teaching. It is not the traditional way where the teacher disseminates his/her knowledge to students sitting in rows in front of him or her. It is an interactive kind of activity where the teacher may skilfully act as the guide while the students discuss the problems with each other. Ideally, teacher and students sit around a table. (For a detailed description of the interactive method, see Kiraly 2000.)

Semantically, or rather lexicologically, we may talk of a lexical divergence here:

FIGURE 7

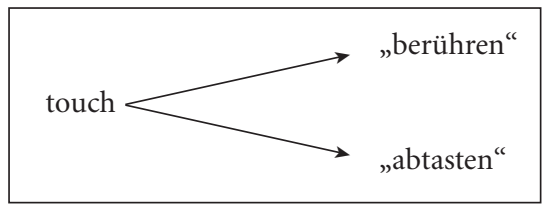

In terms of scenes and frames, what we have in the source text is a frame that fits two scenes (a) a scene where a doctor examines a patient and (b) a scene where a person makes sexual overtures to another person. If we had translated touch by berühren, only the second scene would have been evoked.

It might be argued (Don Kiraly, personal communication) that abtasten does not suggest the sexual harassment scene and that the students could have been guided to anfassen, a word just as generic in its use as "touch."

We can explain the problem, I think, by saying that there is an overlapping of scenes here. There is the scene of a doctor examining a patient, and there is the sexual-harassment scene. With the German words we cannot very easily capture both of them. Neither berühren nor anfassen evokes the examining scene. A doctor would never say: "Legen Sie sich mal hin. Ich möchte Sie mal anfassen / berühren." And 
abtasten does not really carry sexual overtones, or does it? Above all it evokes the surgery scene, but it may, with a little bit of imagination, perhaps ironically, also evoke the sexual-harassment scene. One can imagine a loving couple where he says: "Darf ich dich mal ein bisschen abtasten, mein Schätzchen?" This is, of course, a more-or-less affair. In cognitive (prototype) terms, it is a question of core and fuzzy edges. In our text, when we read the word “touch," the core notion, I expect, will be the surgery scene where a patient is examined, and German abtasten provides an exactly fitting frame, as it were, for this scene. But toward the edges of abtasten there may also be the sexual-harassment notion evoked with a little bit of imaginative (dirty?) thinking on the part of the reader.

In the previous example a scene was provided by a real picture, which is rather exceptional. The present example is typical of the much more normal situation where we have to imagine a scene. With a little help to get started (the verbal stimuli of the teacher) the translators managed to see, or maybe hear, a scene that sparked off a translation, i.e. a frame that fits the scene (with the restrictions mentioned). In Fillmore's terms, a source-text frame is replaced by a target-text frame, which in itself is not very creative. What is creative, though, is the avoidance of a translation for "touch" that springs to mind immediately, namely "berühren," which would not have fitted the scene at all.

\subsection{Scenic detail provided by the source text}

Let us now turn to an example taken from fiction. It is taken from a seminar paper of two of my students. It can be used to illustrate further aspects of cognitive processes. It is a passage from the novel Sushi for Beginners by Marian Keyes. Dylan is about to divorce his wife Clodagh because he found out that she has been having an affair with Markus. There are constant quarrels about who will get custody of the children, who will pay for what, their respective share of the common property, etc. Marcus, her new lover, now regularly comes to see Clodagh. (I have underlined the problematic words.)

In floods of tears, Clodagh opened her front-door. 'What's wrong?' Marcus gasped.

'It's Dylan. He's a bastard.'

What's he done?' Marcus demanded, following her into the kitchen, his face bruised with fury.

'Oh, I deserve it,' Clodagh sat at the table and wiped her leaking eyes. I'm not saying I don't. But it's so hard. Whenever I see him he has more bad news and he makes me feel awful.'

'So what's he done?' Marcus demanded again.

'He made me give back all my credit cards. And he's closed our joint account and instead he's going to give me an allowance every month. For guess how much?'

Sobbing again, she named a sum so low that Marcus exclaimed, 'Allowance? That's more like a forbiddance!'

(Marian Keyes: Sushi for Beginners. London: Penguin Books 2001: 510)

Two subjects' translated this passage and produced a dialogue protocol. One of their problems was the translation of his face bruised with fury.

B: Just imagine: he is in a vile mood

A: But he doesn't know what has happened. She only said that Dylan is a bastard. 
B: Still. Look, he opens the door and she is crying. You see?

A: Yes.

B: "In a floods of tears, Clodagh opened her front-door." This really shocks him. My girlfriend is crying!

A: Yes.

B. Because of this idiot.

A. Yes.

B: And he is really annoyed. And then she begins with her self-accusations, and then he says 'So what's he done?' and he is really cross. You see?

A: Yes. Excited, and he's excited.

B: Excited, excited, because he's annoyed ...Hm

A: Annoyed, furious, excited ...

B: "und folgte ihr mit hochrotem Kopf" (and followed her with a bright red face), haha

A: ha-ha

B: But wait a moment! You get a bright red face when you feel embarrassed.

A: Yes, you're right. But you can also sort of burn with fury (vor Wut glühen), can't you? [There is a lengthy discussion about the appropriateness of burn with fury and other ways of describing his face, but the subjects are not happy with their solutions. Then all of a sudden B says: Fury "aufgebracht sein" [close in meaning to annoyed but "aufgebracht" implies that there is an external reason for the fury]

B: Perhaps "Was hat er getan?" fragte Markus, während er ihr total aufgebracht in die Küche folgte. ('What's he done?' Marcus asked, following her into the kitchen, completely annoyed.)

A: Yes, let's write it down.

B: This looks like a creative translation.

The subjects' visualization is clearly based on the information they get from the text, in cognitive terms, on the bottom-up material. They make a conscious effort at visualizing the scene, but one may ask if this directly leads to the solution. They begin by describing the colour of Marcus' face, but they end up by framing the scene. It is plausible to say that they had the scene at the back of their minds all they way through and also when arriving at "aufgebracht."

What happened here, in terms of scenes-and-frames, is that a scenic detail (face bruised with fury) was translated by a frame (aufgebracht). It is interesting to observe the focus here. The frame aufgebracht may, apart from the colour of the face, include other scenic elements such as a loud voice, a frown, specific gestures etc. but it focuses on the external reason for the annoyance. The back translation ("completely annoyed"), unfortunately, does not really render this nuance. From a point of view of prototype semantics we may say that at the core of the notion aufgebracht there is this external reason. Actually, in the electronic version of the Wahrig Wörterbuch the definition of aufbringen points in that direction:

jemanden aufbringen erzürnen, erregen; dein ständiger Widerspruch bringt ihn auf

Aufgebracht, thus, is a very appropriate translation, since, as we read in the text, what annoys Markus is right in front of his eyes.

One might argue that the vividness and originality of the idiosyncratic expression "bruised with fury" is lost. I agree that an equivalent in German would have been creative indeed. The subjects did not find one. What they found is a word that shows a change when compared with the source text and that adds something that is 
novel by focussing on an external reason for anger. This is in accordance with my definition of a creative translation mentioned in section 1.1 .

\subsection{Scenic details retrieved from memory}

This again is an example taken from a student's paper. (I underlined the problematic words.)

8 p. m. Off to dinner party. All the Smug Marrieds keep inviting me on Saturday nights now I am alone again, seating me opposite an increasingly horrifying selection of single men. It is very kind of them and I appreciate it v. much but it only seems to highlight my emotional failure and isolation - though Magda says I should remember that being single is better than having an adulterous, sexually incontinent husband.

(Helen Fielding: Bridget Jones's Diary, London: Picador 1996)

The subjects dialogue runs:

A: Yes, that's lovely. Smug is "smug smile," I know what it looks like but I don't know the word for it. (Laughter) These are, you know, the people that are settled in their ... nice house with a garden, and then there is the dog, the cat (both subjects laugh)

B: "Spießig" (bourgeois)

A: No. The question is also: Why is it written in capital letters?

B: She probably classifies her friends that are married and so happy and contented in a group, and she has this name for them in her diary.

A: Yes, exactly, the "Smug Marrieds" and the you know ...

A: "Selbstgerecht" (self-righteous), no not "selbstgerecht," what do you call it?

B: "Selbstzufrieden" (self-satisfied)

A: "Selbstzufrieden," does it exist?

B. Yes, I think so, maybe "die ganz ekelhaft glücklich Verheirateten" (the quite disgustingly happily married ones)...

A: That's really very nice!

B. Perhaps "der Club der ganz ekelhaft glücklich Verheirateten" (the club of the disgustingly happily married ones)

The subjects are discussing the translation of Smug Marrieds. There are no scenic details in the text, there is only the frame Smug Marrieds, although the feelings and general attitude of the narrator may be deduced from what she writes in her diary. The subjects here explicitly visualize a scene, a cliché, ("the people that are settled in their ... nice house with a garden, and then there is the dog, the cat"), which, quite obviously, they retrieve from their memory of prototypical scenes. The details of this scene, being part of a cliché are thus core elements by definition, in other words, they are prototypical. The visualization of prototypical elements, in this case, leads to a translation.

Prototypicality, actually, was intuitively made use of by Selescovitch and Lederer in the examples they quote when recommending visualization as a teaching tool. For the translation of the sentence "Children have forgotten how to eat, completely forgotten how to eat," taken from an article on famine in Africa, they suggest visualizing a scene of a little child with bony legs and arms and a blown-up belly, a picture often seen in the media, in order to avoid a mistranslation such as "les enfants ont oublié comment manger" (They have forgotten their good manners). (Selescovitch/Lederer 1989: 25-26.) 
Visualization is a way to achieve creative translations. The translation "der Club der ganz ekelhaft glücklich Verheirateten", which for the final version was slightly modified into "der Club der ganz ekelhaft glücklichen Ehepaare", can be called creative since it contains words expressing a negative attitude not explicitly expressed in the source text but certainly implied. We may say that the phrase highlights the feelings of the narrator.

I am adding a picture in order to make our scene physically visual. Maybe the couple does not look so smug, but they do have a dog.

FIGURE 8

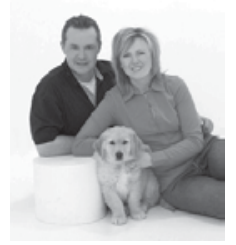

\section{Discussion}

\subsection{Questions concerning my own observations}

The stimuli I observed are by no means comprehensive. There may still be others. I would imagine that observations could be further specified as to the scenic elements that subjects are imagining. Is it core elements only that lead to translations or will fringe elements also be involved?

At the moment it might be interesting to find out which kinds of stimuli lead more easily to successful and creative translations in the end than others: (a) looking at real pictures, (b) looking at suggestive frames in the source text, (c) looking at suggestive scenic details in the source text or (d) imagining scenic details reconstructed from memory.

When working with students the teacher can act as a guide toward visualizations. One may want to find out if the processes I observed can also take place without the guidance of a teacher. The observations of teams of two subjects suggest that they can. But this observation will have to be based on more data.

In this context we may want to know if translators who have had some training in visualization techniques are better than translators without such training. We would have to compare two groups then, but this would involve statistical considerations, since the group as a variable should be kept stable. And this would only be possible if the groups were fairly large.

And when visualizations occur, are they only promoted by group work (brainstorming) or can they also take place within the individual translator? For this purpose, we might compare a single translator working on her/his own with a team of two or more translators solving the same translation problem. Here again statistical considerations would have to be taken into account. The results of these kinds of observations might have a bearing on the working situation of translators in industry. If teamwork is more creative in an economically justifiable way, why not make use of it? 


\subsection{Questions concerning combinations of approaches}

The way I gained my observations may lead to questions about possible combinations of various approaches used in process studies. For instance:

- One may think of combining electronic tools such as Translog, mentioned above. Among other things Translog records pauses. It would be interesting to find out what happens during pauses. Are they occasionally used for visualizations by the subjects? Can we find out about this with concurrent think-aloud protocols and/or by clued retrospection (=retrospective interviews)?

- How can we avoid the danger of ex-post rationalizations inherent in clued retrospection?

- Is there a correlation between the lengths of segments a translator deals with that can be observed via Translog (Jakobsen 2003: 91) and visualizations? Does concurrent think aloud make segments smaller, and if segments get smaller, is there a greater chance for visualizations to take place?

My observations are meant as a beginning. What I wanted to do here is specify my hypothesis about the use of visualizations in translating. It needs to be corroborated - or modified, maybe even falsified - by further research.

\section{REFERENCES}

Alves, F. (ed.) (2003): Triangulating Translation. Perspective in Process Oriented Research, Amsterdam/Philadelphia, John Benjamins.

Barbosa, H. G. \& A. M. S. Neiva (2003): “Using Think-Aloud Protocols to Investigate the Translation Process of Foreign Language Learners and Experienced Translators," in A. FABio (ed.): Triangulating Translation. Perspectives in Process Oriented Research, Amsterdam/Philadelphia, John Benjamins, p. 137-155.

Fillmore, C. J. (1976): "Frame Semantics and the Nature of Language," in J. Harnard et al. (eds.) Origins and Evolution of Language and Speech. Annals of the New York Academy of Sciences, Vol. 280, New York, p. 20-32.

Fillmore, C. J. (1977): 'Scenes-and-Frames Semantics', in A. Zampolli (ed.) Linguistic Structures Processing, Amsterdam, N. Holland, p. 55-88.

GöPFERICH, S. (1998): Interkulturelles Technical Writing. Fachliches adressatengerecht vermitteln. Ein Lehr- und Arbeitsbuch, Tübingen: Narr.

Hansen, G. (ed.) (1999): Probing the Process in Translation: Methods and Results. Copenhagen: Samfundslitteratur, p. 135-149.

Jakoвsen, A. L. (2003): "Effects of Think Aloud on Translation Speed, Revision, and Segmentation" in Fabio Alves (ed.): Triangulating Translation. Perspectives in Process Oriented Research, Amsterdam/Philadelphia: John Benjamins, p. 69-95.

Kiraly, D. (2000): A Social Constructivist Approach to Translator Education: Empowerment from Theory to Practice, Manchester, St. Jerome Publishing.

Koestler, A. (1966): Der göttliche Funke. Der schöpferische Akt in Kunst und Wissenschaft, Bern/ München/Wien, Scherz Verlag.

Kussmaul, P. (2000): Kreatives Übersetzen, Tübingen, Stauffenburg.

Kussmaul, P. (2003): "Der Professionalität auf der Spur." in Nord, Britta / Schmitt, Peter A. (Hrsg.): Traducta Navis. Festschrift zum 60. Geburtstag von Christiane Nord, Tübingen, Stauffenburg.

Lakoff, G. (1987): Women, Fire and Dangerous Things. What Categories Reveal about the Mind, Chicago, University of Chicago Press.

Langacker, R. W. (1987): Foundations of Cognitive Grammar, Stanford: Stanford University Press. Opitz, C. (2004): "Zum Aufschlusswert prozesswissenschaftlicher Untersuchungen für die Übersetzungsdidaktik" in E. Fleischmann, P.A. Sснмitt and G. WotjaK (eds.) Translationskom- 
petenz. Tagungsberichte der LICTRA (Leipzig International Conference on Translation Studies 4.-6.10.2002, Tübingen: Stauffenbur, p. 659-677.

PaCte Group (A. Beeby, M. Fernández Rodríguez, O. Fox, A. Hurtado Albir, W. Neunzig, M. Orozco, M. Presas, P. Rodríguez Inés, L. Romero (Principal investigator: A. Amparo Hurtado), Universitat Autónoma de Barcelona (2003): "Building a Translation Competence Model," in F. Alves (ed.): Triangulating Translation. Perspectives in Process Oriented Research. Amsterdam/Philadelphia John Benjamins, p. 43-66.

Paganao, A., Magalhäes, C \& F. Alves (2004): "Towards the Construction of a Multilingual, Multifunctional Corpus: Factors in the Design and Applications of CORDIALL," TradTerm 10 (volume especial sobre Tradução e Lingüística de Corpus), São Paulo, USP.

Selecovitch, D. (1978): Interpreting for International Conferences, Washington, Pen and booth.

Selecovitch, D. et M. Lederer (1989): Pédagogie raisonnée de l'interprétation. Collection Traductologie $\mathrm{n}^{\circ}$ 4, Brusselles, Didier Érudition.

WiLss, W. (1992): Übersetzungsfertigkeit. Annäherungen an einen komplexen übersetzungspraktischen Begriff. Tübingen, Narr.

Wilss, W. (1996): Übersetzungsunterricht. Eine Einführung. Begriffliche. Grundlagen und methodische Orientierungen, Tübingen, Narr. 